\title{
Relationship of Bone Densitometry and Bone Resorption Markers With Menopausal Type and Duration
}

\author{
Cerrahi ve Doğal Menopozlu Kadınlarda Kemik Dansitometri ve Kemik Yıkım \\ Marker Düzeylerinin Menopoz Tipi Ve Süresi ile ilişkisi
}

\author{
Nermin Akdemir, Cemil Bilir², Hakan Cinemre², Muhittin Pekuz², Feyzi Gökosmanoğlu² \\ IAnkara Keçiören Teaching and Education Hospital, Department of Gynecology and Obstetric, Ankara, Turkey \\ ${ }^{2}$ Düzce University Faculty of Medicine, Department of Internal Medicine, Düzce, Turkey
}

\section{Abstract}

Objective: Menopause age and bone mineral density are positively related and there is a rapid bone loss in the early postmenopausal period. A ratio of $30 \%$ of post-menopausal women are affected from osteoporosis developing due to bone loss and this causes $40 \%$ risk of fracture in a 50 - year old woman.

Materials and Methods: In this sudy, serum osteocalcin and urine deoxypridinoline levels were analyzed in 102 postmenapausal and 48 healthy premenopausal controls who presented to gynecology outpatient clinic. Bone densitometry was obtained from all postmenopausal women. Postmenopausal patients were further divided into four groups according to time since menopause: $<5$ years, 5-9 years, $10-19$ years and $>20$ years.

Results: Mean (SD) age in 48 premenopausal women was 47.7 (3.7) while it was $56.5(6.8)$ in 102 post-menopausal women. 34 out of 102 post-menopausal women had surgical menopause due to bilateral oopheroctomy+hysterectomy while the remaining had natural menopause. No significant difference was found in bone-turnover markers between women with surgical and natural menopause.

Conclusion: Although there was not a statistically significant difference between bone-turnover markers, bone mineral density stays lower in surgical menopausal patients and this difference disappear only after about 20 years. Also bone turnover markers are usually high up to five years after surgical menopause and return to normal levels after then. Thus, our study suggested that oopheroctomy does not cause additional risk to hysterectomy. We also suggest that there is not a longterm relationship between serum bone turnover markers or bone density and the etiology of menopause.

(Turk J Rheumatol 2010; 25: 29-33)

Key words: Surgical menopause, natural menopause, osteoporosis

Received: 30.07 .2008

Accepted: 13.10 .2008
Özet

Amaç: Kadınlarda menopoz yașı ile kemik mineral yoğunluğu arasında pozitif bir iliski mevcut olup menopoz sonrası erken dönemde hızlı bir șekilde kemik kaybı gerçekleșmektedir. Azalmıș kemik yoğunluğu sonrası ortaya çıkan osteoporoz postmenopozal kadınların \%30'unu etkileyerek 50 yașındaki bir kadında \%40 kırık riskine yol açmaktadır.

Yöntem ve Gereçler: Çalıșmamızda Kadın doğum polikliniğimize bașvuran 102 postmenopozal ve kontrol grubunu olușturan 48 premenopozal, toplam 150 hastanın serum ostekalsin ve idrar deoksipridinolin düzeylerine bakıldı. Post menopozal hastaların Kemik dansitometrileri ölçüldü. Calıșmaya alınan postmenopozal hastalar menopoz sürelerine göre 5 yıldan az, 5-9 yıl, 10-19 yıl ve 20 yıl üzeri olacak șekilde 4 gruba ayrıldı.

Bulgular: Calıșmaya alınan toplam 150 hastanın 48'i premenopozal olup yaș ortalamaları 47.7 (SD 3.7), kalan 102 postmenopozal hasta ise 56,5 (SD 6.8) yașındaydı. Postmenopozal 102 hastanın 34 'ü cerrahi menopoz olup bilateral ooferektomi + histerektomili, 68 hasta ise normal menopozlu hastaydı. Cerrahi menopozla doğal menopozlu kadınlarda kemik turnover markerları arasında anlamlı ilișki saptanmadı.

Sonuc: Cerrahi menopozla normal menopozlu hastalar arasında istatiksel olarak anlamlı fark olmasa da kemik mineral yoğunlukları cerrahi menopozlularda daha düșük seyretmekte ve bu fark 20 yıldan sonra eșitlenmektedir. Kemik yıkım ürünleri cerrahi sonrası <5 yıl olan grupta yüksek olup sonraki dönemlerde bu fark ortadan kalkmaktadır. Sonuç olarak histerektomi yapılırken overlerin çıkarılması diğer toplumlarda yapılan çalıșmaların çoğuna benzer sekilde bizim hasta populasyonumuzda da osteoporoz üzerine olumsuz bir risk katmamaktadır. Uzun dönem takibinde cerrahi menopozla normal menopoz arasında kemik yıkım ürünleri ve kemik mineral yoğunluğu açısından anlamlı fark yoktur. (Turk J Rheumatol 2010; 25: 29-33)

Anahtar sözcükler: Cerrahi menopoz, doğal menopoz, osteoporoz

Alındığı Tarih: 30.07.2008 Kabul Tarihi: 13.10.2008 


\section{Introduction}

There is a positive relationship between bone mineral density and menopause duration in women and there is a rapid bone loss in the early post-menopausal period. Bone loss shows a decreasing trend with the aging (1). The frequency of osteoporosis in postmenopausal women is $30 \%$ and women at 50 years of age have $40 \%$ fracture risk (2). Menopause can be considered as natural menopause or surgical menopause in women.

There are conflicting results with respect to development of osteoporosis after hysterectomy. Reduced (3-5), increased $(6,7)$ and unchanged bone mineral density were seen in the studies (8-10). The increased bone resorption markers after the bilateral hysterectomy and oophorectomy revealed by Fiore CE and et al. (11) showed that there was no negative effect of ovaries protective hysterectomy on osteoporosis.

Studies done in various communities yielded controversial results. Also there are no large population studies investigating the relationship between osteoporosis and menopause type.

\section{Materials and Methods}

In this study, serum osteocalcin and urine deoxypridinoline levels were analyzed in 102 postmenopausal and 48 healthy premenopausal controls who presented to gynecology outpatient clinic.

Postmenopausal patients were divided into natural and surgical menopause groups based on the etiology. 48 premenopausal patients constituted the control group (Figure 1). All the study patients who were in the postmenopausal period evaluated by $T$ scores of the femur neck bone mineral density (BMD) and lumbar BMD. Serum osteocalcin and urinary deoxypridinoline levels were measured in premenopausal and postmenopausal patients.

The exclusion criteria are shown in Fig 1. Postmenopausal patients were further divided into four groups according to time since the begining of menopause: $<5$ years, 5-9 years, $10-19$ years and $>20$ years.

\section{Statistical analysis}

Baseline and descriptive data were presented as mean \pm SD for normally distributed data and median and interquartile range for non-normally distributed data. Chi-square test was used for analysis of data when both dependent and independent variables were categorical. Groups were compared by using one-way ANOVA. $\mathrm{P}<0.05$ was set as statistically significant. SPSS 15.0 was used for statistical calculations (SPSS Inc., Chicago, IL, USA).

\section{Results}

The mean (SD) age in 48 premenopausal women was 47.7 (3.7) while it was 56.5 (6.8) in 102 post-menopausal women. Demographic characteristics of the patients are shown in the Table 1.

34 of $102(33 \%)$ post-menopausal women had surgical menopause due to bilateral oopheroctomy +hysterectomy and $68(67 \%)$ had natural menopause. The menopause duration and other characteristics of these two groups are shown in the Table 2 and Table 3.

There was a positively correlation between menopause and urinary deoxypridinoline and serum ostecalcin levels regardless of the body mass index (BMI), history of medications and smoking $(p<0.001)$. There was no significant difference by the age, BMI, smoking and medication between the surgical and natural menopause groups. Also urinary deoxypridinoline, serum ostecalcin levels and BMD scores showed no significant differences between the two groups $(p=0.48, p=0.61)$.

In the surgical menopause group, patients who were in the first 5 years showed a higher level of bone turnover markers but it did not reach a statistical significance. The

\begin{tabular}{lcc}
\multicolumn{3}{l}{ Table 1. General characteristics of patients } \\
\hline Characteristics & $\begin{array}{c}\text { Premenopause } \\
(\mathrm{n}=48)\end{array}$ & $\begin{array}{c}\text { Postmenopause } \\
(\mathrm{n}=102)\end{array}$ \\
\hline Age, mean (SD) & $47.7(3.7)$ & $56.5(6.8)$ \\
BMl, mean (SD) & $29.2(5.5)$ & $30(4.5)$ \\
Osteocalcin, mean (SD) & $2.82(1.7)$ & $4.73(3.5)$ \\
Urine DPD, mean (SD) & $14.6(7.2)$ & $22.8(9.4)$ \\
Alcohol & none & none \\
Smoking & $<5$ packet/year & $<5$ packet/year \\
Diabetes mellitus, n, \% & $10(20.8 \%)$ & $24(23.5 \%)$ \\
Hypertension, $n, \%$ & $8(16 \%)$ & $40(39 \%)$
\end{tabular}

BMI: Body mass index, DPD: Deoxypyridinoline, SD: Standart deviation

Table 2. Characteristics of surgical and natural menopause patients

\begin{tabular}{lccc}
\hline & $\begin{array}{c}\text { Surgical } \\
\text { menopause } \\
(\mathbf{n}=34)\end{array}$ & $\begin{array}{c}\text { Natural } \\
\text { menopause } \\
(\mathbf{n}=68)\end{array}$ & $\begin{array}{c}\boldsymbol{P} \\
\text { value }\end{array}$ \\
\hline Age, mean (SD) & $56.97(6.3)$ & $56.2(7.1)$ & 0.61 \\
BMI, mean (SD) & $30.02(3.9)$ & $30.1(4.7)$ & 0.9 \\
Osteocalcin, mean (SD) & $4.54(3.2)$ & $4.82(3.6)$ & 0.70 \\
Urine DPD, mean (SD) & $22.11(8.6)$ & $23.17(9.8)$ & 0.58 \\
Femur neck BMD, mean (SD) & $-1.297(0.59)$ & $-1.047(1.1)$ & 0.25 \\
Lumbar-BMD, mean (SD) & $-1.632(0.93)$ & $-1.245(1.0)$ & 0.06 \\
Menopause duration, & $11.76(7.4)$ & $8.07(7.1)$ & 0.02 \\
mean (SD) & & & \\
\hline BMl: Body mass index, DPD: Deoxypyridinoline, BMD: Bone mineral densitometry, \\
SD:Standart deviation
\end{tabular}




\section{0 women}

\section{Patient Group}

102 Postmenopausal women

- Urine deoxypyridinonline + Bone mineraldensitometry

- Serum Osteocalcin

\section{Control Group}

48 Premenopausal women

- Urine deoxypyridinonline

- Serum Osteocalcin

\section{Exclusion Criteria:}

- Previously diagnosed and/or treated osteopenia or osteoporosis,

- Hyperthyroidism

- Hyperparathyroidism

- Smoking (social smokers or $<5$ pack / year excluded)

- Chronic renal failure

- Chronic liver disease

- Antihypertensive treatment (especially thiazide diuretics)

- Uncontrolled diabetes mellitus

- History of hospitalization in last 3 months

Figure 1. Study algorithm and exclusion criteria

Table 3. Relationship between menopause duration and BMD, osteocalcin and urine DPD

\begin{tabular}{|c|c|c|c|c|c|c|c|c|}
\hline \multirow[t]{2}{*}{ Menopause duration } & \multirow{2}{*}{$\begin{array}{c}<5 \text { years } \\
\text { SMnp/NMnp }\end{array}$} & \multicolumn{3}{|c|}{$5-9 y}$. & \multirow{2}{*}{$\begin{array}{c}10-19 \text { y. } \\
\text { SMnp/NMnp }\end{array}$} & \multicolumn{3}{|c|}{$>20 \mathrm{y}}$. \\
\hline & & $P$ & SMnp/NMnp & $P$ & & $P$ & SMnp/NMnp & $P$ \\
\hline Number of patients & $10 / 32$ & & $7 / 11$ & & $4 / 15$ & & $13 / 10$ & \\
\hline Osteocalcin, mean & $5.9 / 4.4$ & 0.18 & $3.5 / 4.2$ & 0.21 & $4.8 / 4.5$ & 0.83 & $3.9 / 7.2$ & 0.01 \\
\hline Urine DPD, mean & $22.9 / 20.1$ & 0.58 & $18.3 / 24.2$ & 0.53 & $16 / 25$ & 0.054 & $26.2 / 28.2$ & 0.57 \\
\hline Femur neck BMD, mean & $-0.80 /-0.88$ & 0.82 & $-1.14 /-0.73$ & 0.88 & $-1.5 /-1.0$ & 0.40 & $-1.7 /-1.9$ & 0.58 \\
\hline Lumbar-BMD, mean & $-1.2 /-.90$ & 0.32 & $-1.77 /-1.14$ & 0.68 & $-1.37 /-1.35$ & 0.96 & $-1.9 /-2.0$ & 0.85 \\
\hline Age, mean & $51 / 52$ & 0.59 & $54.1 / 56.9$ & 0.19 & $59.7 / 57$ & 0.27 & $62 / 67.9$ & 0.002 \\
\hline
\end{tabular}

SMnp:Surgical menopause, NMnp:Natural menopause, BMI: Body mass index, DPD: Deoxypyridinoline, BMD: Bone mineral densitometry 
lumbar BMD levels were lower in the surgical menopause group, but this was not in statistically significant level. There was no pathologic fracture in the osteopenic group. Additionally patients who had over 20 years menopause duration had similar BMD scores in both groups. Only, serum osteocalcin levels were higher in the natural menopause group compared to the surgical menopause group $(p=0.01)$.

\section{Discussion}

Although there was not a statistically significant difference between bone-turnover markers, BMD values were lower in surgical menopausal patients and this difference disappeared only after 20 years. Also bone turnover markers are usually high up to five years after surgical menopause and return to normal levels after then.

Prophylactic oophorectomy is suggested after the hysterectomy because the risk of the ovarian cancer in long term (12). However, the ideal age for prophylactic oophorectomy is controversial. In the 1999, The American College of Obstetricians and Gynecologists (ACOG) Association suggested the age alone would not be enough for the prophylactic oophorectomy after the hysterectomy, also familial risk of ovarian cancer and other diseases and risks (cardiovascular risk, osteoporosis risk, the risk of stroke, breast cancer risk, etc.) should be kept in mind (13). Although there are many suggestions about this subject, there is no randomized prospective study in the literature. Hysterectomy in women under the age of 40 with the presence of mutations BRCA $1 / 2$, there is a suggestion of bilateral oophorectomy because of the breast and ovarian cancer risk in future (14). In the Parker and his colleagues study (13), coronary artery disease caused the highest mortality risk in the age of over 65 years of women, hip fracture has the highest mortality risk in the age below the 65 years of women. In our study, patients in the surgical menopause group, showed a higher level of bone turnover within the first 5 years. Although this situation changes after 5 years the difference still was not in statistically significant level. Higher bone turnover markers in early time in the surgery menopause group would be a risk factor of the future bone fracture events but there was no bone fracture in all time period in our study. Serum osteocalcin levels were significantly lower in surgery group of the postmenopausal women for 20 years. This can be explained by the significantly lower of age of the surgical menopause patients.

Donna Kritz-Silverstein et al. (15) followed 447 postmenopausal women, and they didn't show any effect of hysterectomy or oopheroctomy on BMD. Similarly in our study, there were no differences in the BMD and bone turnover markers over 20 years of menopause.
Two studies by, Verit FF et al. (16), Namiduru ES et al. (17) found no relationship between the serum prolidase activity and postmenapausal osteoporosis, but they found significantly higher levels of urine deoxypridinolin in the premenapausal women as our study.

Our study suggests that oopheroctomy does not cause additional risk to hysterectomy and there is not a longterm relationship between serum levels of bone turnover markers BMD and the etiology of menopause.

\section{Conflict of Interest}

No conflict of interest is declared by the authors.

\section{References}

1. Kritz-Silverstein D, Barrett-Connor E. Early menopause, number of reproductive years, and bone mineral density in postmenopausal women. Am J Public Health 1993; 83: 983-8.

2. Halmesmäki $\mathrm{KH}$, Hurskainen RA, Cacciatore $B$, Tiitinen A, Paavonen JA. Effect of hysterectomy or LNG-IUS on serum inhibin B levels and ovarian blood flow. Maturitas 2007; 57: 279-85.

3. Durães Simões $R$, Chada Baracat $E$, Szjenfeld VL, de Lima GR, José Gonçalves W, de Carvalho Ramos Bortoletto C. Effects of simple hysterectomy on bone loss. Sao Paulo Med J 1995; 113: 1012-5.

4. Watson NR, Studd JW, Garnett T, Savvas M, Milligan P. Bone loss after hysterectomy with ovarian conservation. Obstet Gynecol 1995; 86: 72-7.

5. Smeets-Goevaers CG, Lesusink GL, Papapoulos SE, Maartens LW, Keyzer JJ, Weerdenburg JP, et al. The prevalence of low bone mineral density in Dutch perimenopausal women: the Eindhoven perimenopausal osteoporosis study. Osteoporosis Int 1998; 8: 404-9.

6. Tuppurainen M, Kröger H, Saarikoski S, Honkanen R, Alhava $E$. The effect of gynecological risk factors on lumbar and femoral bone mineral density in peri- and postmenopausal women. Maturitas 1995; 21: 137-45.

7. Grainge MJ, Coupland CA, Cliffe SJ, Chilvers CE, Hosking DJ. Reproductive, menstrual and menopausal factors: which are associated with bone mineral density in early postmenopausal women? Osteoporosis Int 2001; 12: 777-87.

8. Carranza-Lira S, Nájera Mojica JL, Herrera J, RamosPonce D, Olivares-Segura A, Cardoso-Saldaña G, et al. Changes in hormones, lipids and symptoms after the administration of a commercial preparation with dehydroepiandrosterone in postmenopausal women. Proc West Pharmacol Soc 2002; 45: 181-3.

9. Larcos G. Hysterectomy with ovarian conservation: effect on bone mineral density. Aust N Z J Obstet Gynaecol 1998; 38: 452-4.

10. Shilbayeh S. Prevalence of osteoporosis and its reproductive risk factors among Jordanian women: a cross-sectional study. Osteoporosis Int 2003; 14: 929-40. 
11. Fiore $C E$, Falcida $E$, Foti $R$, Motta M, Tamburino C. Differences in the time course of the effects of oophorectomy in women on parameters of bone metabolism, and interleukin-1levels in the circulation. Bone Miner 1993; 20: 79-85.

12. Parker WH, Broder MS, Liu Z, Shoupe D, Farquhar C, Berek JS. Ovarian conservation at the time of hysterectomy for benign disease. Clin Obstet Gynecol 2007; 50: 354-61.

13. American College of Obstetricians and Gynecologists. Clinical management guidelines for obstetriciangynecologists. ACOG Practice Bulletin 7. Washington, DC: ACOG; 1999.

14. Armstrong K, Schwartz J, Randall T, Rubin S, Weber B. Hormone replacement therapy and life expectancy after prophylactic oophorectomy in women with BRCA1/2 mutations: a decision analysis. J Clin Oncol 2004; 22: 1045-54.

15. Kritz-Silverstein D, von Mühlen DG, Barrett-Connor E. Hysterectomy and oophorectomy are unrelated to bone loss in older women. Maturitas 2004; 47: 61-9.

16. Verit FF, Geyikli I, Yazgan P, Celik A.Correlations of serum prolidase activity between bone turnover markers and mineral density in postmenopausal osteoporosis. Arch Gynecol Obstet 2006; 274: 133-7.

17. Namiduru ES, Binnur Erbagci A, Celik A, Yilmaz M, Tarakçioglu M. Serum prolidase activity in postmenopausal osteoporosis. Minerva Med 2007; 98: 647-51. 